\title{
THE AMOUNT OF WORLD ORGANIZATION NECESSARY AND POSSIBLE
}

\author{
LELAND M. GOODRICH†
}

\section{I}

IT is a truism, often repeated and most recently illustrated by the atom bomb, that man has made far greater progress in laying bare the mysteries of nature and in harnessing nature's forces to his ends than in formulating and applying principles for governing his social relationships. It is striking and illuminating that the American people, who have made the greatest progress in exploring the secrets of atomic energy and who have been responsible for its successful use for destructive purposes, should be the ones apparently most fearful of the future consequences of its use. We appear to have little confidence in our ability to use our resources and ingenuity to construct an international order which will eliminate the necessity, even the temptation, to use atomic bombs.

Of course the United States alone cannot create a better ordered and more socially satisfactory world. For assurance of world peace, security and general well-being, the cooperative action of many other peoples is required. However, a major responsibility rests upon the American people to propose the means by which this goal is to be realized and to assume leadership in the implementation of common purposes. There is, it seems, little difference of opinion among Americans as to broad objectives. We are all-or at least the overwhelming majority of us-against war and famine and pestilence. We want peace, security, and general prosperity and happiness. We may differ with respect to the intensity of our interest in having these things attained by other peoples. We all want them for ourselves, and we also want them for others if we do not have to sacrifice too much in the process.

Our principal differences arise when we begin to discuss questions of means. Here we find ourselves differing strongly. Some are more sanguine than others as to the possibility of ever attaining the desired goals. Some are more charitable than others in their willingness to make present sacrifices for common ends. Some are more convinced than others of the efficacy of general principles and mechanisms. The infinite variety of the human personality finds expression in the reac-

$\dagger$ Professor of Political Science, Brown University; Director, World Peace Foundation, 1942-6; Professor of International Organization and Administration, Fletcher School of Law and Diplomacy; member of the International Secretariat, United Nations Conference on International Organization, 1945. Editor or joint editor, Documents on American Foreign Relations, Vols. IV-VI. Joint author with Edvard Hambro of Charter of the United Nations: Commentary and Documents. 
tions of individuals-even informed individuals-to this major problem of how our world is to be best ordered for peace and security and human welfare.

At the risk of great oversimplification, I suggest that current attitudes fall into three broad patterns. First, there is the program of those whose basic approach is one of caution and conservatism. These people are skeptical of the possibility of greatly improving relations between different peoples and races within a short span of time. They believe war to be inevitable, or are at least dubious about the possibility of completely eliminating it. They are likely to be intensely national in their point of view and to entertain strong distrusts of foreign peoples, their governments and their ideologies. On the basis of historical experience, as they interpret it, they favor putting their trust in American power and readiness for defense, accepting such assistance as can be obtained without dangerous advance commitments, while keeping the atomic bomb a secret, maintaining a navy and air force vastly superior to any other in the world, and manning far-flung defensive bases. As the fear of Russia grows among the adrocates of this point of view, close collaboration with the members of the British Commonwealth of Nations seems to become a necessary means to meet the growing danger. ${ }^{1}$ But this relationship, like our relationship with our Latin American neighbors, is not to be regarded as in any sense a limitation upon our freedom of action. It is the necessary buttressing of our national power.

Secondly, there is the United Nations program. This is the pattern of action which has come to receive the broadest popular support in the United States, thanks to the work of President Roosevelt and Secretary Hull, and it is this program which has been officially accepted by our Government. We are a part of the United Nations and legally committed to its purposes, principles, and procedures. There is little doubt, however, that confidence in the efficacy of the United Nations has weakened under the impact of recent international developments. The United Nations program seeks to combine nationalism and worldconsciousness by providing for voluntary cooperation among independent states for common purposes. It places at the forefront of its principles that of the sorereign equality of its IIembers, but it imposes definite legal obligations on all Miembers and to some extent subordinates them to an international authority. These obligations follow, however, from express consent under the Charter. Domestic jurisdiction is safeguarded. The right of withdrawal is admitted, though not expressly stated in the Charter. The United Nations, therefore, is in

1. There is evidence, for example, that the cause of the loan to Great Britain was strengthened in certain quarters, usually isolationist, by mounting fear of the intentions and policies of the Soviet Union. 
essence a voluntary association of sovereign states. ${ }^{2}$ The Charter is a treaty. Each Member remains free in all essential respects (with the exception of Members who are not permanent members of the Security Council in respect to enforcement action) to decide its rights and obligations under the Charter. From the point of view of a great power such as the United States, the Charter provides for a system of free cooperation between states which are not required in advance to yield any important right which respectable peace-loving states would normally admit exercising except on provocation. Therefore the willingness of Members to cooperate loyally in the achievement of common purposes is the necessary condition to success.

The third pattern of future action which is receiving more and more support in the United States and in certain foreign countries goes much beyond the United Nations in subordinating the national state to an over-all world authority. This is the method of world government. Whereas the United Nations depends almost entirely, and wholly so far as the great powers are concerned, upon the principle of voluntary cooperation, world government involves the establishment of a world authority which will have effective power within defined limits to enforce its will, either against states or individuals. With the establishment of world government, as the term is here used, the existing national states will, within defined limits, lose their independence and supreme authority. This area of world government may be restricted to the development and control of atomic energy, as is envisaged in the Acheson-Lilienthal Report ${ }^{3}$ and proposals of Mr. Baruch before the United Nations Atomic Energy Commission, ${ }^{4}$ or it may include all, or at least additional, matters of recognized international concern. In principle, the difference between the United Nations and world government is the difference between the Articles of Confederation and the American Constitution.

In general terms, these are the three alternative paths which are represented as leading to the promised land of peace and security and human happiness. Those who advise the first path admit that it will be hard, that it will be much like the one we have been travelling. They seek to console us, however, by saying that this way we have a chance of maintaining our own way of life, of preserving an area of

2. For further comment on the nature of the United Nations and on the particular points raised above, see GoOdRICH and HaMBRo, CharTER of the UNITED NATIONS: COMMENTARY AND Docusents (1946). See also Charter of the United Nations: Report to the President on the Results of the San Francisco Conference by the Chairman of the Uniled Statcs Delegation, The Secretary of State, Dep't of State Conference Ser. No. 71 (1945).

3. A Report on the International Control of Atomic Energy, Dep't of State Publication No. 2498 (1946). at 4-14.

4. See Official Records, United Nations Atomic Energy Cosm. (1946) No. 1, 
peace and security, freedom, and material well-being for ourselves, even though the rest of the world goes from bad to worse. Those who counsel the second path believe in the ultimate perfectibility of man, but are convinced that the road is long. They see the need of raising the material and cultural standards of other peoples nearer to our own before accepting world government. They believe, hovever, that if we combine a proper amount of caution with the spirit of social experimentation and the willingness to trust the good faith of others, we will be able to discover a better way of life and in time raise mankind by the process of agreement to a level of social achievement worthy of man's proven intelligence in other fields. Those who advise the third path warn us that, in fact, the second leads to the same destination as the first, that the peaceful and happy world which appears to lie at the end of the United Nations trail is only a mirage which will fade into war, death and destruction, as inevitably as the isolated Eden of independent nationalism. ${ }^{5}$

To the average citizen this confusion of counsels is disturbing, if not disheartening. Which way is he to turn if the experts cannot agree? There may be little hope of finding a common ground between those who see nothing beyond their own country, whose thinling is dominated by nationalist considerations in their most extreme form, who believe that the rest of the world is so far gone on the road to perdition that we had better concentrate on saving ourselves, and those who take a wider and more optimistic view, envisioning the possibility of assuring our peace and security by intimate collaboration with other peoples. But what about the gradualists and the all-outers, the advocates of international cooperation and the advocates of world government? They have common aims and common concerns for humanity. Is the rift between them equally unbridgeable?

\section{II}

The idea of world government, of one supreme political authority for the peoples of the world, is not new. The Roman Empire, at its greatest extent, included all the world that mattered. Mithin its vast scope peace and order were maintained by the imperial authority. With the break-up of the Empire, the ideal of unity was preserved in the teachings of the Christian Church and found secular expression

5. Emery Reves is explicit on this point. "Let us be clear about one thing. A league of sovereign nation-states is not a step, neither the first step nor the nincty-ninth, toward pasce. Peace is law. The San Francisco league is the pitiful miscarriage of the second World War. We shall have to organize peace independently of the Unholy Alliance stillborn in San Francisco or else we shall delude ourselves by believing in a miracle, until the inevitable march of events into another and greater holocaust teaches us that equal and sovereign power units can never, under any circumstances, under any conditions, coexist paacefully." REves, The ANatony of PEACE (1945) 273-4. 
during the Middle Ages in the Holy Roman Empire, which never succeeded, however, in realizing in fact its extravagant professions. With the rise of the modern state, the ideal of world government continued to thrive in the speculations of writers and statesmen. The influence of new ideas of state sovereignty and nationalism showed itself, however, in the detailed provisions of these plans, as most of them envisaged a league or confederation of the states of Europe falling far short of real government. ${ }^{6}$ An important landmark in the development of thought and practice with regard to world government was the adoption of the American Constitution which proved a pattern by which a common government for ever larger aggregates of peoples might be established while retaining pre-existing state units and respecting within defined limits the autonomy of existing states. While no serious effort was made in the course of the nineteenth century to apply this pattern to the world of national states, federalism nevertheless provided the basis for the political unification of territories inhabited by peoples with important common interests and cultural likenesses as, for example, Germany and Canada.

During the period from the Middle Ages down to modern times, the dominant principle governing the political organization of society in the Western world has been that of state sovereignty. The principle of sovereignty was given its classic exposition by Jean Bodin and was first presented as a weapon to be used by the secular monarch in defending his authority to govern against the rival claims of church and feudal lords. But sovereignty was later given a wider meaning; it was made to express the freedom of the ruler or state from outside limitations as well. This theory of the external sovereignty of the state was difficult to harmonize with an international legal system. Moreover, the concept of state sovereignty, particularly as modified by the rise of nationalism, came to be more and more inadequate in the course of the nineteenth and twentieth centuries for meeting the social, economic and political needs of a world growing interdependent under the impact of scientific progress.

The exercise of sovereign authority within its territorial limits was no longer enough for a state whose economic prosperity was becoming increasingly dependent upon foreign markets for its manufactured goods and foreign sources of supply for raw materials and foodstuffs, and whose security might be endangered by the use made of strategic territories under foreign control. The manner in which other states exercised their authority thus became a matter of serious concern. Changes in the fiscal and commercial policies of foreign countries could have serious repercussions on domestic trade and employment. Fur-

6. On essential details of such plans, see WynNer and LLOYd, SEARCHLIGHT ON PEACE Plans (1944). 
thermore, in the case of so-called backward countries, lacking governments effective by Western standards, advanced industrial and commercial nations found important national interests which called for special protective measures. These influences have been conducive to an increase in the size of political entities and of the areas subject to common government. There has admittedly been a contrary trend, both before and after World War I, under the influence of the idea of self-determination, but experience has shown that many of these new political creations are unable to withstand the expansive pressures resulting from the maladjustment between political organization and economic and technological trends.

The means by which this process of integration has been brought about have been varied. Peoples of similar outlooks and interests have been brought together by agreement, as in the case of the union of the thirteen original states to form the United States, the establishment of the German Empire in 1871 (undoubtedly an element of coercion was present here), and the formation of the Dominion of Canada under the terms of the British North America Act of 1867. In other cases force of one kind or another was used, particularly in the establishment of the colonial empires which flowered in the last half of the nineteenth century and the early years of the twentieth. But while this trend toward larger areas of common goremment took place, the concept of state sovereignty still prevailed within individual areas and toward the outside world. The same forces which led to the extension of the territorial limits of exclusively national government just as inexorably operated to make these new limits in a short time inadequate and to create the need for further extension with the whole world as the only logical terminus. On two occasions, impelled by the logic of a situation as well as by certain aspirations peculiar to its ruling class, Germany sought to achieve the goal of world domination by conquest. This method, though it has never been successful since the time of the Caesars, will remain to tempt the ambitious so long as the obvious disharmony between our international political system and the economic and social world in which we live remains.

Numerous attempts were made during the nineteenth and early twentieth centuries to adapt the international political system to the. emerging economic and technological pattern of the world on the principle of voluntary association of sovereign states. Examples of such attempts are the Universal Postal Union, the International Telegraphic Union and, more recently, the much more ambitious League of Nations and International Labor Organization. The more spectacular failures

7. On the development of international cooperation before World War I, sce Wookf, International Governaient (1916). There is, of course, an extensive literature on the activities of the League of Nations and related organizations. See particularly MxErs, HaNDbook of the League of Nations (1935). 
of the League, as evidenced by the successful aggressions of the Axis states and the outbreak of World War II, tend to overshadow and obscure the solid achievements of these instrumentalities of interna* tional cooperation. Even giving these achievements full weight, however, it must be admitted that the progress to date in bringing international relations into harmony with the facts of the modern technological world has been small indeed.

It seems self-evident that a world which can be circumnavigated by a jet-propelled plane in two days, which is so much an economic entity that a railroad strike in the United States would shortly result in mass starvation in Europe and Asia, and which, according to the scientists, has in the atomic bomb an instrument of destruction against which there is no defense, should be subject to one common government possessing the authority to deal effectively with matters of common concern. A blueprint for such a world government is not too difficult to draw, ${ }^{8}$ as we have plenty of examples of governmental structures that are capable of being expanded and adapted to meet the world situation. Getting general acceptance for our blueprint would of course be another matter. The current endeavor on the part of the British Government to find the constitutional basis for self-government for a united India should be an ample reminder of the difficulties involved.

Let us for the time being concern ourselves only with the essential mechanical features of a system of world government. In the first place, it would be necessary to recognize the principle of one supreme world authority corresponding to that of our national government which, within its sphere, would have the power to make laws, to interpret those laws and to enforce them. In order for this authority to be in fact supreme it would need to have the powver to deal directly with individual violators of the law, ${ }^{9}$ which means that it would need its own police force and its own courts. It would need to be able to recruit individuals directly for this police force. It would need to be able to tax individuals in order to support its activities. While it would also be called upon to deal with states, the experience of our national government shows it would be least effective when dealing with states as such, and that its effectiveness would be directly proportional to its success in by-passing states and dealing directly with individuals.

In order for this power to be exercised independently, without undue

8. See, for example, such detailed plans as those of STrEIT, UNION Now (1939) and Culbertson, Total Peace (1943).

9. The authors of The FEDERALIST expressed the basic idea in these words: "The important truth . . . is that a sovereignty over sovereigns, a government over governments, a legislation for communities, as contradistinguished from individuals, as it is a solecism in theory, so in practice it is subversive of the order and ends of civil polity, by substituting violence in place of law, or the destructive coercion of the sword in place of the mild and salutary coercion of the magistracy." THE FEDERALIST No. XX. 
influence by the governments of states, it would be necessary that the organs of world government be so constituted that they derive their authority from the people, not from governments, and that they be able to function independently of the wills of national governments. Furthermore, some arrangement would have to be worked out by which differences of population, of industrial development, of wealth and of political maturity would be reflected in relative representation. ${ }^{10}$ Obviously a body such as the General Assembly of the United Nations would be inadequate for the purposes of a representative policydetermining and supervisory organ, as no numerous and advanced people such as the people of the United States would be willing to subordinate themselves to a body in which their representation and voting strength were the same as for the people of a small state such as Costa Rica or Luxemburg. Nor would it seem to be desirable to have representatives appointed by governments, as such an arrangement would tend to accentuate national differences and would probably mean that common interests would be neglected. Conceivably a bicameral system such as was found necessary to the solution of a similar, though not nearly so difficult, problem in our own national experience might prove acceptable.

In addition to the supreme representative legislative body, it would be necessary to have a world executive capable of necessarily prompt and efficient action. This rules out any body so constituted that any one member has a veto on the action of the whole. Furthermore the executive, like the legislature, must be so constituted as to derive authority from the people directly or indirectly through their representatives in the world legislature, not from governments. An executive committee or chief executive elected by the legislative body, or a chief executive elected directly by the world electorate would seem to be the possible alternatives.

When we come to the problem of a world court, we seem to be on much less difficult ground and we have much more in our international experience upon which to build. The Permanent Court of International Justice functioned with reasonable satisfaction for a period of twentyfive years as a court to which states might bring their cases. "1 The machinery of its constitution, followed in the Statute of the International Court of Justice, ${ }^{12}$ could be taken over without important change on the assumption that the world legislative body would be bicameral in nature. If a satisfactory basis for weighted representation

10. For proposals to this end, see Sohn, Weighting of Votes in an International Assembly

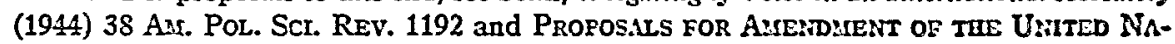
tions Cearter (Sixth Draft, Feb. 1, 1946) made in accordance with Declaration of Dublin Conference of October 11-15, 1945.

11. Hudson, The Persianent Court of Intermational Justice 1920-1942 (1913).

12. Arts. 2-33. 
in a single international assembly should be devised, election of the judges by that body probably would be acceptable. It probably would not be too radical a departure, particularly after the experience of the Nuremburg trials; to give access to the Court to individuals as well as states on certain conditions which might be suggested by our own judicial experience.

The blueprint of world government also would have to define the powers of the organs of world government, particularly of the world legislative body. In current discussions, suggestion is frequently heard that a start be made with the limited authority to control the development and use of atomic energy in all its aspects. While this may be the most immediate matter of common world concern, there can be legitimate doubt whether it would be feasible, except on a purely provisional basis, to establish world government with such limited author ity. It was in effect admitted in the Declaration of November 15, 1945, of President Truman, Prime Minister Atlee and Prime Minister Mac. kenzie King ${ }^{13}$ and in the Resolution of the United Nations General Assembly of January 24,1946,14 that the atomic bomb cannot be dealt with apart from other weapons of mass destruction. It was also recognized in the Declaration of November 15 that no complete protection against the destructive consequences of atomic energy can be provided short of preventing future wars. Furthermore, if an effective inspection system is to be provided, would it not be necessary for the world government to have an effective international force at its command? And how would such a force be maintained without the power to tax and to recruit personnel? And if the war problem is to be successfully dealt with, is it not going to be necessary for the world government to have the authority to deal with international economic, social and political maladjustments and areas of conflict which are productive of war? It may seem the wise tactical approach to propose, first of all, a world authority limited to the control of atomic energy, but it can be doubted whether even that amount of world government will be effective unless accompanied by greater limitations of national authority and larger delegations of power. Furthermore, it might be difficult to get acceptance of a proposal for a world government with exclusively repressive authority.

In outlining a possible pattern of world government, the tacit assumption has been made that it would be largely based on the experience of Western democracies, especially the United States. That is obviously a considerable assumption to make. In the Soviet Union, a different system has been evolved, based on different principles, which has been offered by Marshal Stalin in his pre-election address of Feb-

13. (1945) 13 Dep't of State Bull. 781.

14. See Journal of the Gen. Assembly, 1st Sess. (Jan. 25, 1946) 291-9. 
ruary 9,1946, as a system capable of extension to serve the purposes of world government. ${ }^{15}$ Any serious attempt to construct in detail a plan of world government must take account of the essential features of the Soviet system.

There is undoubtedly much merit in the proposition that a world of freely competing national sovereignties is a tenuous basis upon which to build hopes for peace and security, and that the logical answer to the problem is the immediate establishment of true world government. It certainly would be unwarranted, however, to claim that such world government would guarantee peace, security and happiness for all time to come. Civil war would still be possible, and civil wars can be very bloody and destructive - with long hangovers. However, it is probable that world government is the only reasonably certain means of preventing atomic warfare. Granting this, one problem still remains. Human action, especially mass action, is not always gorerned by reason, and logical proof of the merits of world government gives no assurance that it will be attainable in the near future. We are thus brought back to the question which was earlier raised: what course available today has the best chance of bringing us to the desired end without serious and perhaps disastrous mishaps enroute?

\section{III}

World government can be established (1) by force and (2) by agreement. The experience of the past justifies the conclusion that there is a

15. See N. Y. Times, Feb. 10, 1946, p. 30, col. 3. ". . . [T] he Soviet state system has proved an example of a multi-national state system where the national problem and the problem of collaboration among nations are solved better than any other multi-national state."

The Union of Soviet Socialist Republics, in which approximately 160 different nationalities are contained, is a federal state comprising sixteen Union Republics. "Each Union Republic has its own Constitution, which tales account of the specific features of the Re= public and is drawn up in full conformity with the Constitution of the U.S.S.R." U.S.S.R. Const., Art. 16. "To every Union Republic is reserved the right freely to sccede from the U.S.S.R." Id. Art. 17. The Union Republics are in turn composed of Autonomous Republics, Autonomous Regions, Territories, and Areas which are national or ethnographic in character. The Supreme Soviet (or Council) of the U.S.S.R., which is the supreme legislative body, consists of two chambers: the Soviet (Council) of the Union, elected by the citizens of the U.S.S.R. according to electoral areas on the basis of one deputy for every 300,000 of the population (Id. Art. 34), and the Soviet (Council) of the Nationalities, which is elected on the basis of 25 deputies from each Union Republic, 11 deputies from each Autonomous Republic, five deputies from each Autonomous Region and one deputy from each national area. Id. Art. 35. While the Russian language is the official language of the Cnion, the various Union Republics, Autonomous Republics and Autonomous Regions have their own languages, in which the judicial proceedings of the respective juricdictions are conducted. Id. Art. 110. Discrimination for or against citizens on account of their race or nationality, "as well as any advocacy of racial or national exclusiveness or hatred and contempt," is punishable under the criminal law. Id. Art. 123. 
better chance that the goal will be attained by coercive means than by methods of agreement. As we have seen, the enlargement of areas subject to common government has more commonly been achieved by that means. However, there is also basis in experience for believing that the method of agreement can succeed.

The use of force may conceivably take two forms: (1) military conquest or the threat of military action, and (2) revolution. From the experience of the past, it is fair to conclude that military conquest would not be a particularly satisfactory road to world government since even if the conqueror succeeds in imposing his will, the subjected or coerced peoples will entertain thoughts of regaining their freedom, and disorder and revolution will in all likelihood be recurrent. Perhaps the atomic bomb and other improved means of physical coercion have changed this; more likely they have not. Certainly the United States is not apt to resort to the method of military coercion for the purpose of imposing any plan of world government upon the rest of the world.

The method of revolution is less tried. We know that revolution has been an important and effective means of domestic political action in the past. It has been used more often to divide than to unite. Traditionally, it has been the method by which dissatisfied national minorities have sought to free themselves from alien rule and set themselves up as national states or unite themselves with states to which they are culturally akin. It has also been the method by which internal regimes have been changed, often without serious international consequences. Communism has, however, introduced the technique of world revolution. While Moscow has announced the dissolution of the Third International ${ }^{16}$ and by implication has disavowed the method of world revolution, it seems that Communist parties in different countries still follow policies calculated to meet with the favor of the Russian government. The use of coercion in establishing Communist regimes and in fitting these into a world soviet system would be a possible alternative method of establishing world government by force.

The method of agreement for establishing world government is subject of course to infinite variation as to detail. Nor does it preclude the possibility that force will have to be used to enforce the terms of agreement. Irrespective of the specific means by which the desired consensus is brought about, it is implicit that the people themselves, directly or through their representatives, must agree to the constitution or charter of the new world order. Conceivably this could be achieved either by revising the Charter of the United Nations by the procedures provided for in that document or by an international conference independently called.

16. Resolution of the Presidium of the Executive Commitlee of the Commutnist International, Moscow, May 22, 1943, N. Y. Times, May 23, 1943, p. 30, col. 2; 5 Documents on AMIERICAN Foreign Relations (1944) 527. 
We must not overlook the difficulties that stand in the way of establishing consent on a world basis. Federalization in the past has been achieved by peoples who have had many things in common apart from, or in addition to, a common desire for peace, security and prosperity. The people of the thirteen states who joined to form the United States of America spoke a common language, had a common cultural tradition, had inherited common legal and political ideas, had experienced union under the British Crown, and were faced with common dangers to their security and prosperity. ${ }^{17}$ Similar, though not identical, common attachments existed for the people of Germany, Canada, Switzerland and other countries where analogous political integrations have occurred. When we look at the present world picture, however, we find that divisive factors are much more numerous and influential than common concerns and fears. We see the difficulties experienced by the British Government in finding the basis for a unified self-governing India. We see the repeated setbacks that attend the efforts to unite China. We witness the caution with which Dominion governments approach the problem of a more unified direction of Imperial foreign and military affairs. ${ }^{18}$ We saw the reaction of the leaders of Western European democracies to General Smuts' proposal of November 25, 1943, for a closer partnership with Great Britain. ${ }^{10}$ How much more difficult, if not impossible now, would be an agreement between the Anglo-American countries and those in general sympathy with them, on the one hand, and the Soviet Union and its neighbors, on the other? Perhaps agreement will be possible if fear of Russia grows sufficiently strong to bring the western democracies under a common government, but that would be the final step in the division of the world into two opposing camps, not the consummation of world government in the sense in which that term has here been used.

It may be useful to consider in greater detail some of the difficulties that today stand in the way of realizing world gorernment by consent. Establishing a world government involves the transfer to that body of the authority to take binding decisions on matters which previously have been within the exclusive control of the individual state. Since such decisions will be taken with respect to questions arising from conflicts incapable of resolution solely by the application of previously. accepted rules, there will be involved the exercise of considerable discretionary authority. In order for this process to operate successfully there must pre-exist a wide area of agreement on fundamental matters and a willingness to compromise on others, conditions which are likely

17. Jay, in No. II of The Federalist stresses this point. He notes "that Providence has been pleased to give this one connected country to one united people," and proceeds to detail the aspects of this unity.

18. See Corbett, Britain: Partner for Peace (1946) 64 el seq.

19. Id. at 63 . 
to exist only where people accept the same general system of values, have been in the habit of working together, know and understand each other, and have confidence in each other. It seems obvious that these conditions do not exist generally today.

Language differences make mutual understanding more difficult and delay the process of discussion and accommodation, but the experience of bilingual states such as Canada, Switzerland and Belgium shows that language difference alone is not an impossible barrier. More important than language are the wide range of cultural and ideological differences which affect moral standards, patterns of thought and living habits. Of these perhaps the most divisive at the present time is the difference between the Anglo-American and the Soviet conceptions of democracy. We have seen that the acceptance of democracy as a goal at Yalta marked the beginning instead of the end of differences with regard to the regimes to be established in the defeated and occupied countries of Europe. We have a long way to go in the process of mutual accommodation before the peoples of the Anglo-American countries and of the Soviet Union can participate in world government on the basis of agreement on fundamental political principles. Finally, the extent of racial, religious and economic differences among the peoples of the world makes it highly unlikely that in the near future any country such as the United States will accept regulation by a world government of such matters as international movements of populations and international trade and commerce.

If this is a fair estimate of present prospects of realizing world government, except possibly within the atomic energy field (and as we have seen, there are reasons for doubting the feasibility of such a limited approach), is there a reasonable chance of attaining the goal by the less spectacular method of evolutionary development? It is necessary here to make an important distinction between what might be called organic evolution and organizational evolution. Probably the organs of the United Nations as they stand under the Charter are not capable of gradual change into organs of real world government. They are essentially organs for facilitating cooperation between sovereign states. When and if it becomes possible to establish real world government, their character will need to be completely changed. That is particularly true of the General Assembly, the Security Council, the Economic and Social Council, and the Trusteeship Council. On the other hand, it is quite conceivable that after considerable experience in working together, the governments of Member States will be prepared to call a General Conference to make a fundamental revision of the Charter. This new Charter would then come into force according to the provisions of Article 109 or perhaps according to special provisions adopted by the Conference itself. In a sense this could amount to a peaceful revolution, but on the other hand the process would be evolutionary 
in the sense that the new Charter would be built on the basis of experience with the old and the means of transition to the new order would have been provided in the old.

If we take this view of the means by which world government is ultimately to be attained, what is the role indicated for the United Nations in the years ahead? Certainly not to give the quickest possible demonstration of its own incompetence, because in so doing it would prepare its own demise without necessarily making possible the establishment of a more effective world order. As I see it, the role of the United Nations in the years ahead will be highly important and constructive. To a considerable extent, the task of the United Nations will be educational:20 to help peoples and their representatives know each other better and to understand each other's purposes and interests, to familiarize them with the problems which they face in their relations with each other, and to assist them to develop attitudes and procedures for facilitating the resolution of differences.

It should not be claimed that the United Nations as it stands offers an adequate means for dealing with matters of international concern. However, we err in overemphasizing the importance of mechanism if we condemn it outright on that ground. It does offer the means by which governments having confidence in each other's good faith can make some substantial progress in developing the habit of working together peacefully and cooperatively. Our historical experience does not show that a system based on national sovereignty necessarily degenerates into war. There is a considerable amount of evidence that sovereign states can develop relationships among themselves that give reasonable assurance of peace, security and economic welfare. Mitness relations between the United States and Canada, the United States and Great Britain, Great Britain and France, the Scandinavian countries, the Low Countries, and certain of the Latin American Republics.

In certain respects the United Nations Charter is undoubtedly defective as a means of promoting voluntary cooperation, and it should therefore be revised at the earliest opportunity. In other respects, the need is for the establishment of practices which will aroid possible deficiencies or at least mitigate Charter defects. It would inspire greater confidence in the United Nations, particularly among the smaller states, if the Charter contained some provision establishing a more definite standard with regard to the obligation of MIembers not to use force and the obligation of Members, particularly the permanent members of the Security Council, to take action in the presence of an illicit use of force. ${ }^{21}$ Under the Charter Members are obligated to ac-

20. Not limited, however, to the activities of UNESCO.

21. Proposals to this effect were made at San Francisco but were successfully resisted by the Delegations of the Sponsoring Governments. Goodsicu and Hussaro, op. cit. stspro note 2 , at 67,155 . 
cept the decisions of the Security Council calling for enforcement action, but until such decision is actually taken, no obligation exists. It would also inspire greater confidence in the United Nations, and particularly in the Great Powers, if the use of the veto were further restricted, either by amendment to the Charter or in practice, so as to make it possible for the Security Council to act more effectively as an instrument of unbiased world opinion in all matters except where the taking of enforcement action is in question. ${ }^{22}$ The right of the General Assembly to discuss freely all matters of international concern must be maintained, and where the matter is not actually before the Security Council for action, the right to make recommendations must be equally respected. It will be unfortunate if these rights of the General Assembly are in any respects limited by a broad interpretation of Article 2, paragraph 7, safeguarding domestic jurisdiction, or by abuse of its prerogatives by the Security Council. Furthermore, it will be unfortunate if the Charter provisions authorizing studies and recommendations by the General Assembly and the Economic and Social Council are interpreted to exclude the use of persons not representing governments in the making of such studies and reports. The employment of compe. tent independent people will do much to clarify and elucidate difficult international problems and assist in the establishment of satisfactory international standards. It would be a considerable improvement in the system of peaceful settlement of disputes if the Statute of the Court, an integral part of the Charter, were modified to confer compulsory jurisdiction on the Court in legal disputes. This would make certain harmonizing changes in the provisions of Chapter VI of the Charter desirable, if not necessary. While the Trusteeship System in certain respects is an improvement over the League Mandates System, certain defects in the Charter's relevant provisions have already been demonstrated. The provisions covering the composition of the Trusteeship Council and the negotiation of trusteeship agreements should be revised to eliminate some of the confusion that has thus far arisen.

But while certain changes in the Charter may be desirable in the interest of a more effective instrument of cooperation, it would be a mistaké, I think, at this time to place the emphasis on Charter revision. In spite of kinks and imperfections, the Charter is a workable instrument of international cooperation if there is a will and desire on the part of members to make it work. The obstacles to fruitful international cooperation may be too great to overcome. In that case the United Nations will fail. But in that case, too, there is no chance that real world government can be established. To attempt to establish world government before the conditions necessary to its success exist may

22. For discussion at San Francisco, see Goodruce and HAMBro, op. cil. supra note 2, at 124 et seq. 
well cause the opposite of the desired effect; it may, for example, hasten the division of the world into two irreconcilably opposed and hostile groups. The obstacles to the immediate attainment of a rational organization of the world cannot be eliminated by simply refusing to recognize them. 